\title{
A split mouth clinical study to compare Subepithelial connective tissue graft and Guided tissue regeneration in the treatment of Miller's class I and II gingival recession.
}

\begin{abstract}
Background: Gingival recession (GR) can result in hypersensitivity, esthetic concern to the patient, and chances for root caries. The purpose of this randomized clinical study was to evaluate the effect of guided tissue regeneration (GTR) procedure using a bioabsorbable collagen membrane in comparison to autogenous Subepithelial connective tissue graft (SCTG) for root coverage in Miller's class I and II gingival recession defects.

Materials and methods: In this split mouth study, 10 patients with 20 contralateral Miller's class I or II recession defects were randomly treated with coronally advanced flap using either Subepithelial connective tissue graft (control group) or resorbable collagen membrane (experimental group). The clinical evaluations were done using plaque index, gingival index, height of gingival recession, probing sulcus depth and clinical attachment level at baseline, 3 and 6 months post- operatively.

Results: Data analysis was done using descriptive statistics and student's t test was used for comparisons. $P$ value $<0.01$ was considered to be significant. Both the groups showed complete resolution of the defects at 6 months post operatively. Inter group comparison between both the groups at 6 months showed no statistically significant differences in any of the clinical parameters.

Conclusion: Predictable outcome were observed in both the groups and indicated that collagen based guided tissue regeneration membrane i.e. ProGide can be safely used.

Key-words: Gingival recession, Guided tissue regeneration, Subepithelial connective tissue graft

Key Messages: SCTG is considered as the gold standard treatment for gingival recession but involves a secondary donor site which at times may cause discomfort and pain to the patient. This study showed comparable clinical results using collagen based resorbable guided tissue regeneration membrane and Subepithelial connective tissue graft for treatment of recession defects suggesting ProGide collagen membrane as a safe and biocompatible alternative to SCTG.
\end{abstract}

\section{Introduction:}

The apical shift of the marginal gingiva beyond cementenamel junction on the root surface termed as Gingival recession. [1]The following etiologic factors have been implicated in gingival recession: faulty tooth brushing technique, tooth malposition, gingival inflammation and abnormal frenumattachment[2] and is more prevalent in females than in males.[3]

Correction of position \& morphology and dimension of the gingiva are the ultimate aims of periodontal plastic surgery.[4] The Subepithelial Connective Tissue Graft (SCTG) results a high degree of predictable success as it provides dual blood supply as well as better colour match. Thus it is considered to

\begin{tabular}{|l|l|}
\hline \multicolumn{3}{|c|}{ Access this article online } \\
\hline \multirow{2}{*}{$\begin{array}{l}\text { Website: } \\
\text { www.ujds.in }\end{array}$} & Quick Response Code \\
\hline $\begin{array}{l}\text { DOI: } \\
\text { https://doi.org/10.21276/ujds.2020.6.3.3 }\end{array}$ \\
\hline
\end{tabular}

be a Gold standard in the treatment of gingival recession.[5]More recently, Guided Tissue Regeneration (GTR) can be used as a treatment modality for various root

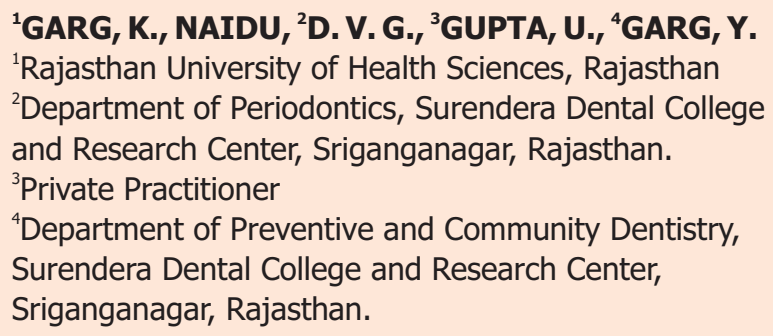

Address for Corresponding : Dr. Kamal Garg College Campus Address- Flat no. 11, Staff Quarters, Surendera Dental College and Research Center, Sriganganagar, Rajasthan.

Email id: kamalgarg1064@rediffmail.com

Received : 7 Sep. 2020, Published : 31 Dec. 2020

How to cite this article: Garg, K., Naidu, D. V. G., Gupta, U., \& Garg, Y. (2021). A split mouth clinical study to compare Subepithelial connective tissue graft and Guided tissue regeneration in the treatment of Miller's class I and II gingival recession. UNIVERSITY JOURNAL OF DENTALSCIENCES, 6(3). 
coverage procedure.6Guided tissue regeneration provides healing by formation of new cementum, periodontal ligament and bone over the exposed root surface thereby attaining better outcome.

\section{Aim \& Objectives:}

AIM: - Comparison of contralateral Miller's class I and II gingival recession with a bioabsorabable collagen membrane i.e. GTR membrane and Subepithelial connective tissue graft six months post- operatively.

OBJECTIVES: - To assess the efficacy of Subepithelial connective tissue graft and Guided tissue regeneration membrane in patients with contralateral gingival recession with following parameters.

1. Reduction in probing sulcus depth (PSD).

2. Reduction in the height of gingival recession (GR).

3. Increase in the amount of attached gingiva (AG).

4. Gain in the clinical attachment level (CAL).

\section{Materials \& Methods}

Patients age ranging 18- 50 years with contralateral minimum $3 \mathrm{~mm}$ buccal Miller's class I and II recession, sufficient palatal donor tissue for obtaining connective tissue graft as well as probing depth less than or equal to $4 \mathrm{~mm}$ at recession area were included in the study were selected from outpatient department.

Exclusion Criteria: Patient having known allergy/ sensitivity to any medication to be used in this study, Use of any tobacco products, Patient who is medically compromised and under medication which affects the healing process. Patient who is not able to maintain oral hygiene, Patient should not have used any antibiotic from past six months prior to the initiation of treatment, Treated area teeth should not have undergone any endodontic procedure and Patient should not be pregnant.

20 sites in ten patients were selected. The selected sites were divided into control site and experimental site.

Clinical data collection- the following clinical measurements were recorded in the groups at baseline as well as 3 and 6 months post- operatively. Plaque index, Gingival index, Height of gingival recession, Probing sulcus depth (figure 1,2), Width of attached gingiva, Clinical attachment level.

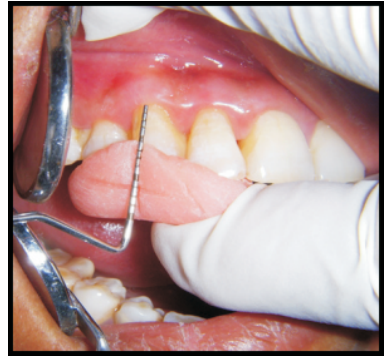

Figure 1: - Presurgical measurement at the control site with the Stent for measuring probing sulcus depth.

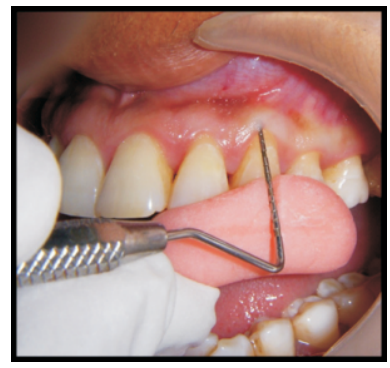

Figure 2: - Presurgical measurement at the experimental site with the Stent for measuring probing sulcus depth.

Data will be analysed statistically to -

1) Evaluate the results achieved with each procedure individually over time.

2) Compare the results obtained with the two procedures after 3 and 6 months.

\section{Pre-surgical Procedure:}

Following initial examination and treatment planning, the selected subjects had undergone phase I therapy. Oral hygiene instructions were explained to patients and those patients who maintained optimum oral hygiene were selected to surgical procedure.

\section{Surgical Management:}

CONTROL SITEAfter giving incisions (figure 3) and flap elevation (figure 4) using periosteal elevator, a sterile surgical template was applied (figure 5) and trimmed accordingly. To get the same size of graft, a template (figure 6) was used on the palate to harvest donor connective tissue. The graft harvested as described by Bruno.The connective tissue graft was used on the root surface for this procedure (figure 7). 2 interproximal resorbable 5- 0 chromic catgut suture were used for the graft stability (figure 8 ). Coronally positioned flap completely covered the connective tissue graft and excessive tension was avoided while doing black silk suture on the flap 
(figure 9) and sutures were also placed on the donor area (figure 10).

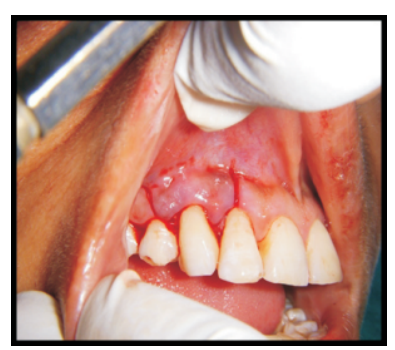

Figure 3: - Incisions given on surgical site.

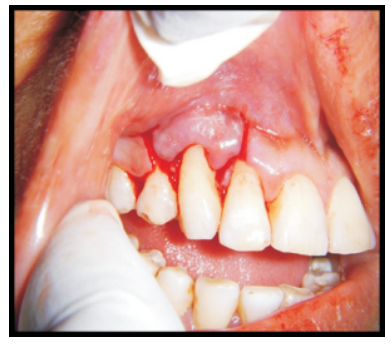

Figure 4: - Flap elevated.

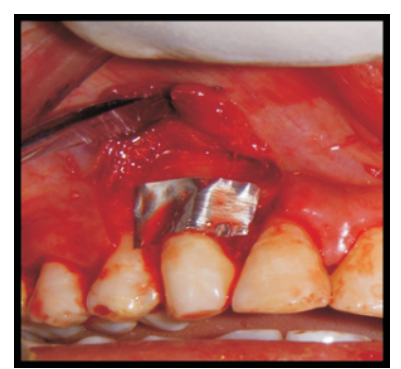

Figure 5: - Template placed on surgical site.

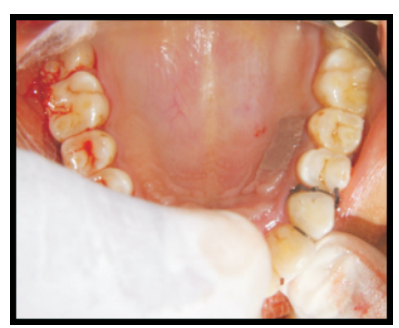

Figure 6: - Template placed on donor area.

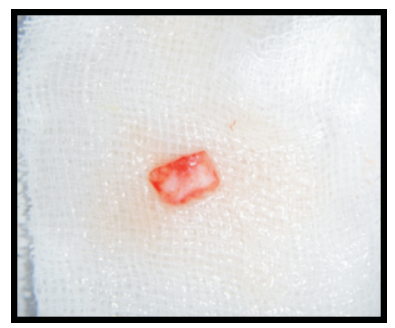

Figure 7: - Graft obtained form palatal area.

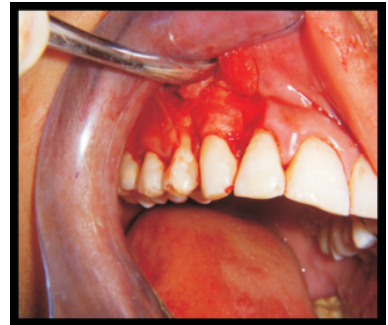

Figure 8: - Graft sutured.

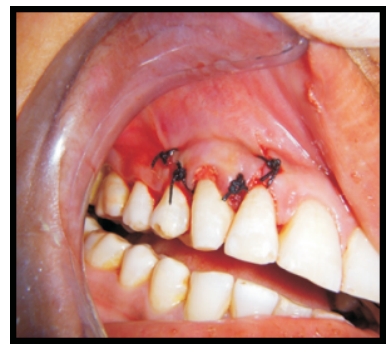

Figure 9: - Flap sutured.

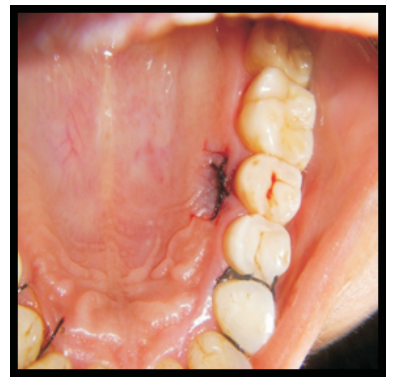

Figure 10: - Donor area sutured.

EXPERIMENTAL SITEAfter giving incisions (figure 11) and flap elevation (figure 12) using periosteal elevator, a sterile surgical template was applied (figure 13) and trimmed. The prepared site was covered with a bioabsorbable collagen membrane (ProGideTM) of same size of surgical template (figure 14). The membrane was adapted on the root surface and adaptation was done in such a manner that GTR membrane covers $2 \mathrm{~mm}$ more than the bone defect margin. Excessive tension on the flap was avoided while doing suturing (figure 15). Periodontal dressing were not used in control (Subepithelial connective tissue graft) and experimental (guided tissue regeneration) group.

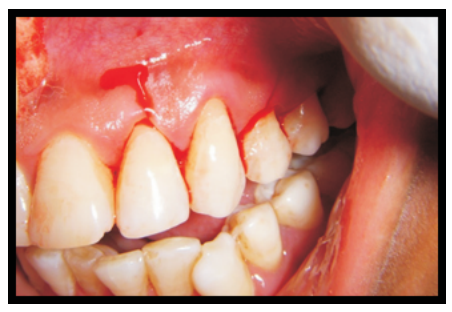

Figure 11: - Incisions given on surgical site. 


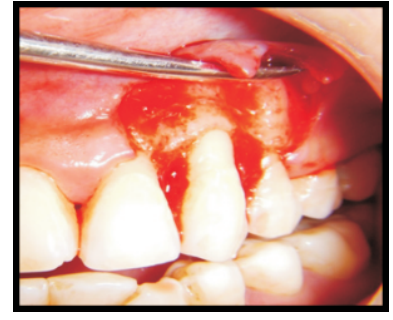

Figure 12: - Flap elevated.

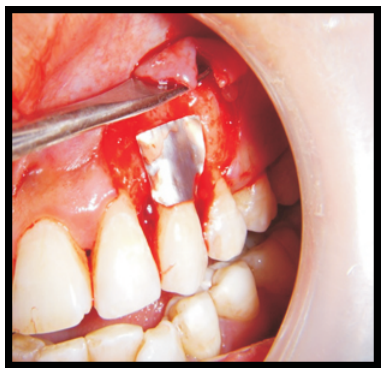

Figure 13: - Template placed on surgical site.

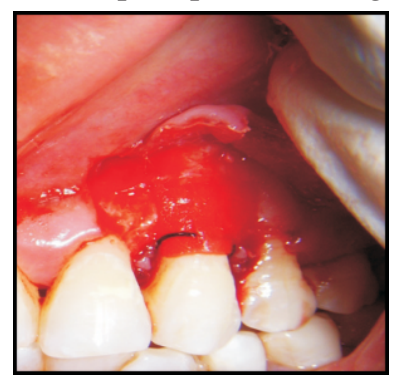

Figure 14: - ProGide sutured.

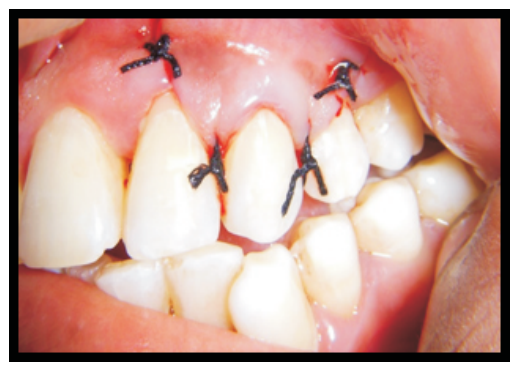

Figure 15: - Flap sutured.

\section{Post-surgical Procedure:}

After seven days of surgery, sutures were removed carefully and saline was used for irrigation. Patients were motivated to use chlorhexidine one week following surgery, sutures were removed and the area was irrigated thoroughly with saline. Patientswereinstructed to rinse with chlorhexidine mouthwash twice daily for another one week. Clinical measurements were assessed at baseline; three and six month's intervals (figure 16, 17, 18)

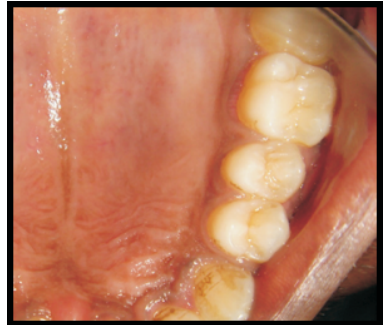

Figure 16: - Post- operative 6 months

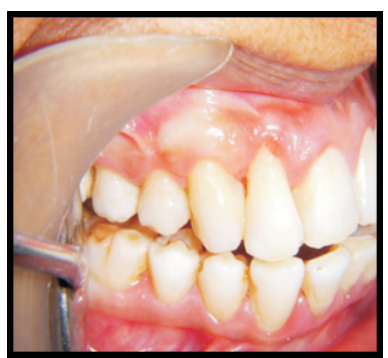

Figure 17: - Post- operative 6 months.

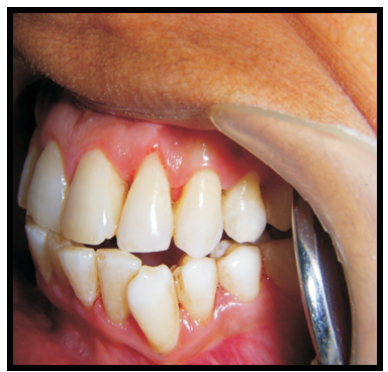

Figure 18: - Post- operative 6 months.

\section{Data Analysis :}

Data analyses were recorded using Descriptive statistics and student $t$ test. Comparisons were also drawn for the changed plaque index, gingival index, height of gingival recession, probing sulcus depth, width of attached gingival and clinical attachment loss.

\section{Results :}

All the ten subjects fully co- operated during and after the study and completed the study. No signs of swelling, infection, flap displacement, haematoma and necrosis were reported.

The mean change in the plaque index scores between control and experimental groups at baseline, 3 months and 6 months revealed differences of $0.09,0.09$ and 0.03 respectively, which were not statistically significant (Table 1)

The mean change in the gingival index scores between control 
and experimental groups at baseline, 3 months and 6 months revealed differences of $0.10,0.14$ and 0.20 respectively which were statistically not significant. (Table 2)

The mean change in the probing sulcus depth scores between control and experimental groups at baseline, 3 months and 6 months revealed differences of $0.10,0.34$ and 0.20 respectively which were statistically not significant (Table 3 ) The mean change in the height of gingival recession scores between control and experimental groups at baseline, 3 months and 6 months revealed differences of $0.00,0.20$ and 0.30 respectively which was statistically not significant (Table 4)

The mean change in the clinical attachment level scores between control and experimental site at baseline, 3 months and 6 months revealed differences of $0.10,0.10$ and 0.20 respectively which were statistically not significant (Table 5) The mean change in the width of attached gingiva scores between control and experimental site at baseline, 3 months and 6 months revealed differences of $0.10,0.20$ and 0.00 respectively which were statistically not significant (Table 6) List of figures

Table 1 Mean reduction in Plaque index

\begin{tabular}{|l|c|c|c|c|l|l|l|l|}
\hline & \multicolumn{2}{|c|}{ Control } & \multicolumn{2}{c|}{ Experimental } & Mean difference & $t$ & P value & S/ NS \\
\hline & Mean & SD & Mean & SD & & & & \\
\hline B & 1.790 & 0.1449 & 1.880 & 0.1135 & 0.090 & 1.546 & 0.140 & NS \\
\hline 3M & 1.420 & 0.2348 & 1.430 & 0.1636 & 0.090 & 0.111 & 0.913 & NS \\
\hline 6M & 1.280 & 0.2658 & 1.250 & 0.1581 & 0.030 & 0.307 & 0.763 & NS \\
\hline
\end{tabular}

If $\mathrm{P}$ value $<0.01$ then $\mathrm{p}$ value is statistically significant.

$\mathrm{B}=$ at baseline, $3 \mathrm{M}=$ at three months , $6 \mathrm{M}=$ at six months, $\mathrm{SD}=$ standard deviation

$\mathrm{t}$ - test value, $\mathrm{p}$ value $=$ probability value, $\mathrm{S}=$ significant, $\mathrm{NS}=$ not significant

Table 2 Mean reduction in Gingival index

\begin{tabular}{|l|c|c|c|c|l|l|l|l|}
\hline & \multicolumn{2}{|c|}{ Control } & \multicolumn{2}{|c|}{ Experimental } & $\begin{array}{l}\text { Mean } \\
\text { difference }\end{array}$ & t & $\begin{array}{l}\text { P } \\
\text { value }\end{array}$ & $\begin{array}{l}\text { NS } \\
\text { NS }\end{array}$ \\
\hline & Mean & SD & Mean & SD & & & & \\
\hline B & 1.300 & 0.1247 & 1.400 & 0.1700 & 0.100 & 0.1 .500 & .151 & NS \\
\hline $3 \mathrm{M}$ & 1.070 & 0.949 & 1.210 & 0.2025 & 0.1400 & 1.980 & 0.063 & NS \\
\hline $6 \mathrm{M}$ & 1.010 & 0.1370 & 0.990 & 0.1524 & 0.0200 & 0.309 & 0.761 & NS \\
\hline
\end{tabular}

If $\mathrm{P}$ value $<0.01$ then $\mathrm{p}$ value is statistically significant.

$\mathrm{B}=$ at baseline , $3 \mathrm{M}=$ at three months , $6 \mathrm{M}=$ at six months, $\mathrm{SD}=$ standard deviation

$\mathrm{t}$ - test value, $\mathrm{p}$ value $=$ probability value, $\mathrm{S}=$ significant, $\mathrm{NS}=$ not significant
Table 3 Mean reduction in probing sulcus depth

\begin{tabular}{|l|c|c|c|c|l|l|l|l|}
\hline & \multicolumn{2}{|c|}{ Control } & \multicolumn{2}{c|}{ Experimental } & $\begin{array}{l}\text { Mean } \\
\text { difference }\end{array}$ & $t$ & $\begin{array}{l}\text { P } \\
\text { value }\end{array}$ & $\begin{array}{l}\text { S/ } \\
\text { NS }\end{array}$ \\
\hline & Mean & SD & Mean & SD & & & & \\
\hline B & 2.90 & 0.568 & 3.00 & 0.816 & 0.100 & 0.318 & 0.754 & NS \\
\hline $3 \mathrm{M}$ & 1.80 & 0.6302 & 1.70 & 0.675 & 0.100 & 0.342 & 0.736 & NS \\
\hline $6 \mathrm{M}$ & 1.70 & 0.675 & 1.50 & 0.707 & 0.200 & 0.647 & 0.526 & NS \\
\hline
\end{tabular}

If $\mathrm{P}$ value $<0.01$ then $\mathrm{p}$ value is statistically significant.

$\mathrm{B}=$ at baseline , $3 \mathrm{M}=$ at three months , $6 \mathrm{M}=$ at six months, $\mathrm{SD}=$ standard deviation

t- test value, $\mathrm{p}$ value $=$ probability value, $\mathrm{S}=$ significant, $\mathrm{NS}=$ not significant

Table 4 Mean reduction in height of gingival recession

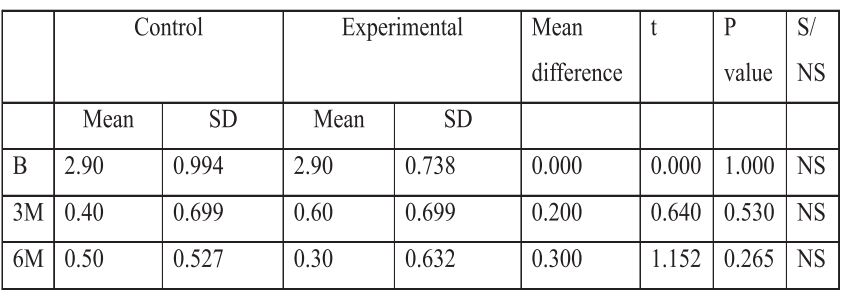

If $\mathrm{P}$ value $<0.01$ then $\mathrm{p}$ value is statistically significant.

$\mathrm{B}=$ at baseline , $3 \mathrm{M}=$ at three months , $6 \mathrm{M}=$ at six months, $\mathrm{SD}=$ standard deviation

$\mathrm{t}$ - test value, $\mathrm{p}$ value $=$ probability value, $\mathrm{S}=$ significant, $\mathrm{NS}=$ not significant

Table 5 Mean gain in clinical attachment level

\begin{tabular}{|l|l|c|c|c|l|l|l|l|}
\hline & \multicolumn{2}{|c|}{ Control } & \multicolumn{2}{|c|}{ Experimental } & $\begin{array}{l}\text { Mean } \\
\text { difference }\end{array}$ & $\mathrm{t}$ & $\begin{array}{l}\mathrm{P} \\
\text { value }\end{array}$ & $\begin{array}{l}\text { S/ } \\
\text { NS }\end{array}$ \\
\hline & Mean & SD & Mean & SD & & & & \\
\hline B & 5.80 & 0.632 & 5.90 & 1.197 & 0.100 & 0.234 & 0.818 & NS \\
\hline $3 \mathrm{M}$ & 2.20 & 0.632 & 2.30 & 0.949 & 0.100 & 0.227 & 0.785 & NS \\
\hline $6 \mathrm{M}$ & 2.10 & 0.876 & 2.30 & 0.949 & 0.200 & 0.490 & 0.630 & NS \\
\hline
\end{tabular}

If $\mathrm{P}$ value $<0.01$ then $\mathrm{p}$ value is statistically significant.

$\mathrm{B}=$ at baseline , $3 \mathrm{M}=$ at three months , $6 \mathrm{M}=$ at six months, $\mathrm{SD}=$ standard deviation

$\mathrm{t}$ - test value, $\mathrm{p}$ value $=$ probability value, $\mathrm{S}=$ significant, $\mathrm{NS}=$ not significant

Table 6 Mean gain in width of attached gingiva

\begin{tabular}{|l|l|l|l|l|l|l|l|l|}
\hline & \multicolumn{2}{|c|}{ Control } & \multicolumn{2}{c|}{ Experimental } & $\begin{array}{l}\text { Mean } \\
\text { difference }\end{array}$ & $\mathrm{t}$ & $\begin{array}{l}\mathrm{P} \\
\text { value }\end{array}$ & $\begin{array}{l}\text { S/ } \\
\text { NS }\end{array}$ \\
\hline & Mean & \multicolumn{1}{|c|}{ SD } & \multicolumn{1}{|c|}{ Mean } & \multicolumn{1}{c|}{ SD } & & & & \\
\hline B & 0.30 & 0.483 & 0.40 & 0.516 & 0.100 & 0.447 & 0.660 & $\mathrm{NS}$ \\
\hline 3M & 2.90 & 0.568 & 2.70 & 0.675 & 0.200 & 0.717 & 0.482 & $\mathrm{NS}$ \\
\hline $6 \mathrm{M}$ & 2.50 & 0.850 & 2.50 & 8.50 & 0.000 & 0.000 & 1.00 & $\mathrm{NS}$ \\
\hline
\end{tabular}

If $\mathrm{P}$ value $<0.01$ then $\mathrm{p}$ value is statistically significant.

$\mathrm{B}=$ at baseline , $3 \mathrm{M}=$ at three months , $6 \mathrm{M}=$ at six months, $\mathrm{SD}=$ standard deviation

$\mathrm{t}$ - test value, $\mathrm{p}$ value $=$ probability value, $\mathrm{S}=$ significant, $\mathrm{NS}=$ not significant 


\section{Discussion:}

The present study was undertaken with the aim of comparing the results obtained in treating gingival recession with GTR membrane to that with connective tissue graft so far as root coverage is concerned. Besides measuring only the height of gingival recession, other parameters such as clinical attachment level, probing sulcus depth and width of attached gingiva were recorded to give a view about the predictability and long-term success of both the procedures. Although six months may be considered short as far as the evaluation period is concerned, several studies including that of Trombelli et al (2004)[7] have shown that the results achieved in the following six months after recession coverage surgery remain largely stable over a ten-year period.

Subepithelial connective tissue graft consistently provides predictable root coverage along with excellent aesthetics (Robert Carvalho da Silva, et al, 2004). [8] It increases the width of keratinised tissue, thereby ensuring long-term success of root coverage surgery. A number of modifications have been advocated through the years to this 'tried-andtested' technique, but the basic principles have remained essentially the same (Langer and Langer, 1985, Harris et al, 1992, Bruno, 1994,).[9] In the present study, the connective tissue graft was harvested from the palatal mucosa and covered with coronally displaced flap.

Use of GTR membranes has been advocated to treat gingival recession, on the premise that there would be formation of new attachment at the site of recession. As per Melcher's hypothesis, use of GTR membrane would ensure that the periodontal ligament fibroblasts are primarily involved in healing at the site of recession. Furthermore, O'Brien et al (1995)[10] have demonstrated that submembranous blood clot is sufficient for regeneration of the periodontal structures. The same has been reported by the studies conducted by Elizabeth P. Rosetti et al (2000)[11] and Paolantonio (2002).[12]Moreover, it would eliminate the need for second surgical site.

In the present study, plaque index was recorded primarily to assess whether the patients were maintaining optimum oral hygiene or not. At the control site, baseline plaque index was $1.79 \pm 0.144$ which reduced to $1.42 \pm 0.23$ at 3 months and $1.28 \pm 0.26$ after 6 months. Similarly, baseline plaque index at experimental site was $1.88 \pm 0.11$ which reduced to $1.43 \pm$ 0.163 at 3 months and $1.25 \pm 0.15$ at 6 months. Although intragroup plaque scores showed significant reduction, intergroup comparison revealed no statistically significant differences. Hence, as the results indicate, significant plaque index reduction was observed in all patients in both the groups. Gingival index was recorded primarily to assess the condition of the gingiva throughout the duration of the study. Statistically significant reduction in gingival index was observed in all the patients of both the groups. At the control site, baseline gingival index was $1.34 \pm 0.12$, which reduced to $1.07 \pm 0.09$ at 3 months and $1.01 \pm 0.13$ at 6 months. Similarly, baseline gingival index at experimental site was $1.40 \pm 0.17$, which reduced to $1.21 \pm 0.20$ after 3 months and $0.99 \pm 0.11$ after 6 months. The comparison of gingival index scores between the experimental group and the control group showed no statistically significant difference. The reduction observed in the gingival index represents a significant improvement in the condition of the gingiva, which may be due to optimum oral hygiene maintained by the patient along with frequent recall visits to reinforce proper maintenance. Probing sulcus depth is considered as the landmark for evaluating the success of periodontal therapy. In the present study, analysis of the results shows statistically significant reduction in probing sulcus depth in both the groups. At the control site, probing sulcus depth was $2.90 \pm 0.56$ at baseline, which reduced to $1.80 \pm 0.63$ after 3 months. It marginally reduced to $1.70 \pm 0.67$ after six months, showing a total reduction of $1.2 \mathrm{~mm}$. At experimental site, probing sulcus depth was $3.00 \pm 0.81$ at baseline, which reduced to $1.70 \pm$ 0.67 after 3 months and reduced slightly more to $1.50 \pm 0.70$ after six months, showing a total reduction of $1.5 \mathrm{~mm}$. The reduction seen in the probing sulcus depth is consistent with the findings of Elizabeth P. Rosetti et al (2000) [11] who found a reduction of $1.4 \mathrm{~mm}$ and $0.84 \mathrm{~mm}$ with the use of GTR membrane and connective tissue graft, respectively. On the other hand, a study by Paolantonio (2002)[12] showed no statistically significant reduction in the probing sulcus depth with the use of connective tissue graft or with GTR membrane. On comparing the probing sulcus depth reduction, no statistically significant difference was found between the two groups, although sites where GTR membrane was used showed slightly better results $(0.3 \mathrm{~mm})$.

Clinical attachment level for the control site was $5.80 \pm 0.63$ at baseline, which reduced to $2.20 \pm 0.63$ after three months. At 6 months, this value reduced to $2.10 \pm 0.87$, showing a total gain of $3.7 \mathrm{~mm}$ in clinical attachment. This is consistent with the finding of Robert Carvalho da Silva, et al (2004) [8]who showed a gain of $3.5 \mathrm{~mm}$ with the use of connective tissue graft. At the experimental site, baseline value was $5.90 \pm 1.19$, which reduced to $2.30 \pm 0.94$ after three months. The mean 
value remained unchanged after six months, showing a total gain of $2.6 \mathrm{~mm}$ in clinical attachment. The gain in clinical attachment level was statistically highly significant, and was similar to the findings of Paolantonio (2002) [12] who also reported highly significant gain in clinical attachment level $(3.9 \mathrm{~mm})$ with the use of GTR membrane. Comparison between the two groups revealed no statistically significant difference. The findings of the present study were found to be consistent with those of Christine Romagna-Genon (2001) [13] who reported a gain in clinical attachment level of $3.3 \mathrm{~mm}$ and $3.1 \mathrm{~mm}$ after six months with the use of GTR membrane and connective tissue graft, respectively.

At control site, the height of gingival recession at baseline was $2.94 \pm 0.99$ which reduced to $0.40 \pm 0.699$ and $0.50 \pm 0.52$ at three months and six months, respectively. The results show that almost all cases showed complete or nearly complete root coverage with the use of connective tissue graft, the mean reduction being $2.45 \mathrm{~mm}$. These findings are consistent with those Arthur B. Novaes, et al (2001) [14]who reported mean root coverage of $1.9 \mathrm{~mm}$ and Borghetti et al (1999) [15] who reported a mean coverage of $2.9 \mathrm{~mm}(76 \%)$ with the use of connective tissue graft. In terms of percentage, $83.3 \%$ of mean root coverage was achieved in the sites treated with connective tissue graft. At experimental site, the height of gingival recession at baseline was $2.90 \pm 0.99$ which reduced to $0.60 \pm 0.699$ and $0.80 \pm 0.63$ after three months and six months, respectively, showing mean root coverage of $2.1 \mathrm{~mm}$ after six months. Elizabeth P. Rosetti et al (2000)[11] reported similar findings in their study, showing mean root coverage of $2.6 \mathrm{~mm}(84 \%)$ with the use of GTR membrane in the treatment of gingival recession. In the present study, $72.5 \%$ mean root coverage was achieved with the use of GTR membrane. Comparison of mean reduction in height of gingival recession between the two groups was found to be statistically not significantly different. Christine Romagna-Genon (2001)[13] reported a decrease of $2.7 \mathrm{~mm}$ and $3.2 \mathrm{~mm}$ in the recession depth with the use of GTR membrane and connective tissue graft, respectively, thus showing no statistically significant difference in the two treatment modalities.

Width of attached gingiva at the control site at baseline was $0.30 \pm 0.48$. This value was increased to $2.90 \pm 0.56$ after three months, which was statistically significant. At six months this value decreased slightly to $2.50 \pm 0.85$. Thus, there was a mean gain in the width of attached gingiva by $2.2 \mathrm{~mm}$, which was found to be statistically highly significant. This finding is consistent with that of Paolantonio (2002),[12] who reported a gain of $2.3 \mathrm{~mm}$. However, Elizabeth P. Rosetti et al 2000 [11] reported an increase in the width of keratinisedtissue by $3.5 \mathrm{~mm}$ while, on the other hand, the study by Arthur B Novaes et al (2001)[14] reported a gain of $1.2 \mathrm{~mm}$ only. These variations may be due to the amount of keratinised tissue present prior to surgery. For experimental site, the baseline values were $0.40 \pm 0.51$. At three months and six months value was $2.70 \pm 0.67$ and $2.50 \pm 0.85$, respectively, showing an increase of $2.1 \mathrm{~mm}$ in the width of attached gingiva, which was statistically highly significant. Elizabeth P. Rosetti et al 2000 [11] reported an increase of $1.5 \mathrm{~mm}$, while Trombelli et al (2004)[7] reported an increase of $1.3 \mathrm{~mm}$ in the width of keratinised tissue, which were statistically highly significant. On the other hand, Paolantonio (2002)[12] reported a gain of $0.2 \mathrm{~mm}$ only, which was statistically not significant. The increased amount of gain in the width of attached gingiva observed in the present study may be due to the use of collagen-based GTR membrane, which has been reported to increase the thickness of keratinised tissue because of its inherent characteristics (Christine Romagna-Genon, 2001).[13]

Intergroup comparison showed that there was no statistically significant difference between the control and the experimental site so far as the gain in width of attached gingiva is concerned. This contradicts the finding of Elizabeth P. Rosetti et al 2000[11] who reported statistically significant difference between the two groups.

It is interesting to note that although there was statistically no significant difference between the two groups as far as various parameters recorded were concerned, the results do reveal a mean coverage of $83.3 \%$ with the use of connective tissue graft and $72.4 \%$ with those sites treated with GTR membrane while, on the other hand, the amount of probing sulcus depth reduction was found to be slightly better $(0.3 \mathrm{~mm})$ in the group treated with GTR membrane. However, hardly any difference was observed between the two groups with regards to changes in mean clinical attachment levels and the width of attached gingiva.

\section{Summary \& Conclusion :}

This present split- mouth clinical study was undertaken to assess the efficacy of collagen-based resorbable GTR membrane and Subepithelial connective tissue graft in the treatment of Miller's Class I and Class II gingival recession. Split-mouth design was followed to minimize individual variation in the healing response 
The following Conclusions were drawn from the present study:

1. Significant reduction in plaque $\&$ gingival index in both groups over a period of six months.

2. Probing pocket depth reduction was similar in both groups.

3. Gain in clinical attachment level in control and experimental sites.

4. Sites treated with GTR and connective tissue graft showed complete resolution of recession defect.

5. Gain in width of attached gingiva in control and experimental sites.

6. Progide used in present study is a safe material and showed promising results.

\section{Reference:}

1. Loe H, Aneurd A, Boysen H. The natural history periodontal diseases in man; prevalence; severity and extent of gingival recession. J Periodontol 1992;63:489495.

2. Sogannaes RF. Periodontal significance of intraoral frictional ablation. J West SocPeriodontol 1977; 25: 112.

3. Gormann WJ. Prevalence and etiology of gingival recession. J Periodontol 1967; 38: 316-322.

4. American academy of Periodontology. Glossary of periodontal terms, 4th ed. Chicago. The American Academy of Periodontology 2001; 49.

5. Langer B, Langer L. Subepithelial connective tissues graft technique for root coverage. J Periodontol 1985; 56: 715-720.

6. Tinti C., Vincenzi G. Treatment of gingival recession by GTR technique with gore- tex membrane clinical variation. Quintessence Int 1990; 6: 465-4

7. Trombelli L, Farina R., Scabbia A. Guided tissue regeneration in human gingival recessions. J ClinPeriodontol 2005; 32: 16- 20.

8. Robert Carvalho Da Silva, Julio Cesar Joly, Antonio Fernando Martorelli de Lima. Root coverage using the coronally positioned flap with or without a Subepithelial connective tissue graft. J Periodontol 2004; 75: 413- 419.

9. Langer B, Langer L. Subepithelial connective tissues graft technique for root coverage. J Periodontol 1985; 56 : 715-720.

10. O` Brien WD, Mishkin DJ, Engler WO, Miller MC, Neville BW. GTR using a biodegradable membrane for new attachment: A clinical, histological, and histometric study in dogs. Int J Periodontics Restorative Dent 1995; 15: 446-461.
11. Elizabeth P. Rosetti, Rosemary Adriana C., Marcantonio, Carlos RossssaJr, Eros S. Chaves, Gilbert Golssis. Treatment of gingival recession: comparative study between subepithelial connective tissue graft and guided tissue regeneration. J Periodontol 2000; 71: 14411447

12. Michele Paolantonio. Treatment of gingival recessions by combined periodontal regenerative technique, Guided tissue regeneration, and subpedicle connective tissue graft. A comparative clinical study. J Periodontol 2002; 73:53-62.

13. Christine Romagna- Genon. Comparative clinical study of guided tissue regeneration with a bioabsorbable bilayer collagen membrane and subepithelial connective tissue graft. J Periodontol 2001; 72: 1258- 1264.

14. Arthur B. Novaes Jr., Daniela C., Gustavo O., Molina et al. Comparative 6 - month clinical study of a subepithelial connective tissue graft and acellular dermal tissue graft for the treatment of gingival recession. J Periodontol 2001; 72: 177-1484.

15. Borghetti A, Glise J-M, Monnet-Corti V, Dejou J. Comparative clinical study of a bioabsorbable membrane and subepithelial connective tissue graft in a treatment of human gingival recession. J Periodontol 1999; 70: 123-130. 